\title{
Presentació. Educació i ocupació
}

Aquest volum miscel-lani de PAPers. RevisTa de Sociologia presenta diversos articles sobre la relació entre educació i ocupació. En alguns casos hi ha una sobreeducació generalitzada o relativa, respecte al lloc de treball que s'ocupa i a la categoria professional, fruit de les transformacions socials esdevingudes a Espanya en les últimes cinc dècades. El nivell d'acceptabilitat de determinades feines per part de la població espanyola explica també que, a l'altre extrem de l'escala ocupacional, alguns immigrants treballin al camp andalús subempleats $\mathrm{o}$ en condicions laborals i de residència inacceptables per qualsevol ciutadà espanyol. Aquestes disparitats afecten també algunes dones, en situació de minoria social, tot i representar demogràficament la majoria. És així que les polítiques familiars pròpies d'un estat de benestar sòlid, d'una banda, i la violència de gènere, de l'altra, siguin presents en les anàlisis sobre la situació social espanyola contemporània. La visió de l'educació superior a la Xina permet comparar-la amb altres indrets del món. Altres temes centrals a Espanya, com la consciencia identitària en la societat basca o la participació institucional dels llatinoamericans, s'exposen en el present volum de PAPERS. Completen el volum dues notes d'investigació metodològiques sobre els efectes de la regularització d'immigrants el 2005. 